\title{
Implementation of PAUD Unit Accreditation in South Padangsidimpuan City
}

\author{
Revi Hervita Suryani Nasution ${ }^{1}$, Khadijah $^{2}$, Ali Imran Sinaga ${ }^{3}$ \\ ${ }^{1,2,3}$ Islamic Education of Universitas Islam Negeri Sumatera Utara, Medan, Indonesia
}

\begin{abstract}
School accreditation is school assessment activities that are carried out systematically and comprehensively through selfevaluation and external evaluation (visitation) activities to determine the feasibility and performance of the school. Accreditation has a meaning as a comprehensive assessment process of the appropriateness and performance of an institution or an educational program as a form of public accountability, a self regulation tool in which schools recognize strengths and weaknesses and continuously improve strengths and improve their weaknesses. This understanding will give more meaning in the results as an acknowledgment, a school has met the specified eligibility standards. Padangsidimpuan City as one of the cities in Indonesia is not immune from the policy to carry out accreditation in each of its educational institutions or units. Some education units have carried out accreditation in the District of South Padangsidimpuan. In carrying out accreditation, the institution certainly cannot be separated from the constraints that must arise, both internal and external constraints. Government efforts to develop human resources through PAUD and PAUD education units have encouraged education units to meet eight (8) National Education Standards (SNP). In the framework of meeting these standards, the central government and regional governments prepare education units to be ready to be accredited on an ongoing and ongoing basis in the hope that the accreditation process can improve the quality of education units. Especially in the city of Padangsidimpuan, South Padangsidimpuan Subdistrict. Based on the results of the interviews. Obtained data from the Padangsidimpuan City Education Office for South Padangsidmpuan Subdistrict, with a total of 17 units, more than 50\% have been accredited, 9 are accredited institutions and 8 institutions have $B$ grades and 1 institution with a value of $C$. Provide an overview of the level of school performance that is used as a tool for coaching, developing and improving schools both in terms of quality, effectiveness, efficiency, productivity and innovation. Providing guarantees to the public that the school has been accredited and provides educational services that meet national accreditation standards.
\end{abstract}

Keywords

Tikrar Method; memorization of the Qur'an

\section{Introduction}

The quality of education is one of the central issues of national education in addition to issues of equity, relevance, and efficiency in managing education. Amendment of Law No. 2 of 1989 became Law No. 20 of 2003 concerning National Education System was followed by the implementation of policies in the implementation of quality basic education. The policy serves to ease the burden and increase public participation in achieving a minimum 
education by prioritizing quality education. Improving the quality of Human Resources through the provision of quality education is a necessity to respond to the demands of globalization which is characterized by free trade early in the 21 st century.

The world of education is inseparable with the existence of a process of evaluation and accreditation that is often a benchmark of the quality of a formal or non-formal education institution. The process of evaluation or in English is often referred to as evaluation is a process of measurement and comparison of the results of work in fact achieved with the results that should be achieved. In order for the quality of education to be as expected by the community, measurement standards are needed. If the desired standard is national, then the standard should also be national as well. Actually, accreditation is well known to many people. The accreditation by the National Accreditation Board recognizes the appropriateness of a public or private educational institution in providing educational services. As for the PAUD level, the accreditation of the National Accreditation Board for Early Childhood Education and Non-Formal Education.

School accreditation is school assessment activities that are carried out systematically and comprehensively through self-evaluation and external evaluation (visitation) activities to determine the feasibility and performance of the school. Accreditation has a meaning as a comprehensive assessment process of the appropriateness and performance of an institution or an educational program as a form of public accountability, a self regulation tool in which schools recognize strengths and weaknesses and continuously improve strengths and improve their weaknesses. This understanding will give more meaning in the results as an acknowledgment, a school has met the specified eligibility standards. Padangsidimpuan City as one of the cities in Indonesia is not immune from the policy to carry out accreditation in each of its educational institutions or units. Some education units have carried out accreditation in the District of South Padangsidimpuan. In carrying out accreditation, the institution certainly cannot be separated from the constraints that must arise, both internal and external constraints.

\section{Review of Literature}

PAUD and PAUD accreditation is an activity of evaluating the feasibility of an PAUD and PAUD education unit based on the criteria established to provide quality assurance for education. In its operational PAUD accreditation and PAUD and PAUD Accreditation Policies and Mechanisms in 2018 (7) PAUD uses assessment instruments that are designed based on open criteria. These criteria were developed from eight (8) SNPs. The results of accreditation itself are a form of public accountability that must be carried out objectively, fairly, transparently, and comprehensively. (BANPAUD-PAUD: 23).

Accreditation is the opposite direction of self-evaluation. What is meant by selfevaluation here is the assessment of outsiders in order to provide recognition of the quality of education held. So in a nutshell it can be said that accreditation is an assessment of the level of quality qualifications of private schools by the government. The recognition results from accreditation has the consequence of recognizing the position of private schools as "Registered" (less), "Recognized" (good), and "Equated" (very good). ( Ma'mur, 2011:184).

PAUD accreditation rating is valid for 5 (five) years from the accreditation rating is determined, schools are required to request re-accreditation, before 6 (six) months the validity of the accreditation rating expires, and for schools whose accreditation ranking expires and refuses to be re-accredited by BAN PAUD then the relevant accreditation rating is declared invalid. (Permendikbud: 2018: 15).

The objectives of school accreditation are as follows: (1) Obtain an overview of school 
performance that can be used as a tool for fostering, developing and improving the quality of education, (2) Determining the level of eligibility of a school in providing educational services. (Arifin, 2005: 118).

Arikunto (2011:260-261) explains the purpose of accreditation is as follows: (1) Obtaining materials for planning efforts to provide assistance in the context of school development, (2) Encouraging and maintaining the quality of education in accordance with the provisions of the curriculum applicable, (3) Encouraging and maintaining the quality of the teaching staff, (4) encouraging the availability of good educational infrastructure, (5) Encouraging the creation and maintaining the preservation of school resilience in the development of schools as a cultural center, (6) Protecting the community from lack of educational efforts responsible, (7) Providing information to the public about the quality of school education, and (8) Facilitating arrangements for transferring students from one school to another.

An accreditation body is an institution established by the Office of Education that is authorized to carry out accreditation. School accreditation bodies are non-structural bodies that are independent. Accreditation bodies have the task of formulating policies and implementing accreditation policies. The accreditation body specifically has the following functions: (1) Formulation of policies and determination of school accreditation tools, (2) Implementation of policy socialization and school accreditation tools, (3) Implementation of accreditation in schools, (4) Evaluation of the implementation of school accreditation, and (5) Reporting the results of overall school accreditation (Arifin, 2005: 120).

The accreditation is related to the study of the quality of education in schools. In this case the quality of education is defined as the ability of schools in operational management and efficient of components related to schools, so as to produce added value to these components according to applicable norms or standards. (Danim, 2003:78-79). In line with this explanation Fattah (2002:1) emphasized that schools as institutions for conducting education are systems that have various interrelated tools and elements that require empowerment.

The quality of education is simply a specific target of educational goals (Bastian, 2006: 184). In the context of education understanding of quality refers to the educational process and educational outcomes. In the educational process, the input includes teaching materials (cognitive, affective or psychomotor), methodology, school facilities, administrative support, infrastructure and other resources, and creating a conducive atmosphere. Quality in the context of educational outcomes refers to the achievements achieved by schools at any given time (Suryosubroto, 2004: 210).

Education quality criteria, quality/success of education is seen from three sides, namely achievement, atmosphere, and economy. Two main standards for measuring quality, namely: (1) results and service standards, and (2) customer standards. Indicators included in the results and service standards are conformance to specifications, fitness for purpose or use, zero defects, and right first time, every team. The meaning is contained here that the standard of educational outcomes includes the specifications of knowledge, skills and attitudes obtained by students, the results of education can be utilized in the community or in the world of work; very small error rate; work right from the start, and right for the next job. Indicators included in customer standards are consumer satisfaction, exceeding customer expectation, and delighting the customer. Thus, customer standards include the fulfillment of satisfaction, hope, and enlighten life for that customer (Danim, 2003: 79-80).

Quality improvement are ways of increasing quality at an unprecedented level (breakthroughs). The steps are as follows: (1) Building the facilities and infrastructure needed to ensure annual quality improvement, (2) Recognizing the special needs for improvement 
improvement projects, (3) For each product form a project team with clear responsibilities to bring the project to reach success, and (4) Providing the resources, motivation and training needed by the team to diagnose the cause, stimulating the determination of the way of healing and setting obstacles to maintaining the acquisition (Juran, 1995: 22-24).

\section{Research Method}

This research is classified as a field research methodology (field study) with a naturalistic approach in collecting data and the researcher himself as the main instrument. This research was conducted at PAUD Institution in South Padangsidimpuan Subdistrict, Padangsidimpuan City. The research instrument was the researchers themselves with data collection techniques used were observation, interviews and documentation. The analysis technique used is Mile and Huberman. To strengthen the validity of the data and findings of research results, the researcher refers to the use of standards consisting of: credibility, transferability, dependability. and confirmability .

\section{Discussion}

Preparation for PAUD unit accreditation in Padangsidimpuan City, South Padangsidimpuan Subdistrict is done systematically where all units have the right to submit accreditation independently with the provisions if they meet the requirements including general requirements and special requirements, namely: (1) General Requirements namely: (a) 1. Institutions must have National Education Unit Number and fill in Dapodik, (b) 2. Submit an application for accreditation to BAN PAUD PNF through the Accreditation Assessment System (Sispena-2) PAUD and PNF, and (c) Has an Operating License/Operating Permit / Establishment License Programs for which accreditation is proposed from the District / City / Ministry of Religion Education Office, UPT Licensing, or other Government Institutions that are authorized and are still valid, (d) 4. The unit is required to submit all programs implemented in accordance with Dapodik, and (2) Special Requirements, namely: ( a) The number of students is a minimum of 10 children in the last school year, (b) At least have one educator or head of unit who has a competency certificate in PAUD which is indicated by a certificate following the training, (c) Has an Education Unit Level Curriculum (KTSP) developed by each unit.

Accreditation preparation is carried out by each unit by preparing all documents in accordance with the accreditation instrument. Obstacles to the accreditation of PAUD City Padangsidimpuan Kec. South Padangsidimpuan lies in the lack or lack of unit knowledge about the fulfillment of 8 National Education Standards (SNP) that are in line with PAUD accreditation instruments. Educator qualifications that do not meet the standards and competence of educators also become a separate obstacle. Constraints of inadequate facilities and infrastructure in accordance with the number of students to be things to be considered. The unit should be able to dig up information from various media related to accreditation, besides that the unit can also obtain information from the Education Office as a partner who always facilitates PAUD units to participate in various accreditation related activities such as the Accreditation Technical Guidance which is carried out continuously. The constraints faced are certainly a challenge for the unit PAUD to continue to carry out accreditation.

Implementation of PAUD unit accreditation in south Padangsidimpuan City has already reached $50 \%$ of the total number of people in South Padangsidmpuan district which 
certainly cannot be separated from the support of the Education Office which always motivates and supports PAUD units in submitting accreditation.

The implementation of accreditation carried out by PAUD institutions changes every year even though the aim is the same to assess PAUD units in meeting the 8 National Education Standards (SNP). In 2018 the assessment conducted is still focused on the completeness of institutional documents that are so focused in meeting the standard is not to the learning process that is carried out, so the institution only fulfills a pile of files that may only be for the requirements only. The file is also uploaded in the Sispena 1.0 application so that what is stated in the sispena application is the focus of the assessment team assessment. At the assessment stage (visitation) assessors pass assessments by following the procedures in the application sispena 1.0 where the feasibility assessment according to the standard refers to the completeness of the documents available at the institution when visited.

Educational units are also given the opportunity to fulfill incomplete documents during the visitation. The score or score is carried out by the assessor based on points set from standard 1 to standard 8 . The assessment conducted by the assessor only takes place within 1 day with a predetermined time of from 08.00 WIB until 17.00 WIB. In 2019 the accreditation assessment underwent a change in the assessment contained in the instrument, where the assessment from standard 1 to standard 8 was carried out using the Sispena 2.0 application. In the Sispena 2.0 application, the unit submitted accreditation by uploading documents to the application which would later be assessed by BAN PAUD AND PNF whether it is sufficient to be feasible to proceed to the next stage, namely the visitation stage. Different from in 2018 the assessment is focused on fulfilling documents according to 8 standards, where in 2019 the document is only as meeting the requirements to be visited. Assessment is focused on implementation in the field which means that Visitation assessors make a maximum assessment of the entire sequence of teaching and learning activities carried out in the unit being assessed. The assessors conduct assessments starting from the activities of welcoming children, teaching and learning, teacher teaching attitudes, how the curriculum and overall implementation spirit of the assessment is on the accreditation instrument. The implementation of the visitation carried out by the assessor takes place in just one working day and for completeness of documents is no longer a priority. The assessment is made in the form of video recordings and photos during the visitation which will later become evidence uploaded to the sispena 2.0 accreditation assessment application.

Visitation is not the end of the accreditation assessment series but there is still a next stage which is the validation phase which is only carried out by assessors who meet the requirements. The validation phase is the final stage which is carried out before the final value determination stage. The validation stage is carried out by the validated assessors, where the validation assessors will conduct an assessment of the assessment of the visitation assessors. by the visitation assessor with the provisions that the supporting documents at the time of the visitation are not in accordance with the specified assessment criteria. Validation assessors can also contact a visitation assessor if an assessment discrepancy is found to ask for clarity so that there is no misinterpretation before the final assessment. on a site that can be accessed by all units that have submitted by logging in using their respective NPSN units.

The difference in the assessment system from 2018 and 2019 is an effort to improve the accreditation assessment system that is more relevant and accurate. The value that has been issued by BAN PAUD is not an irrevocable value, meaning the unit has the right to appeal if the unit feels the value is expended incompatible with submitting an appeal directly to BAN PAUD. The appeal will be processed if the unit makes a proposal no later than a month after the value is issued on the official website. The appeal is the unit's right if deemed not as expected by preparing supporting evidence. validation assessors, units as plaintiffs and 
BAN PAUD secretariat. Appeals will be carried out within a specified time. In the appeals process the value may change from the stipulated but can also depend on the agreement when the appeal hearing takes place.

PAUD unit accreditation in Padangsidmpuan Selatan District certainly has a positive impact on the unit specifically and for the Education Office in general. PAUD units that are not accredited also become motivated to participate in applying for accreditation because they know the benefits of the accreditation. The impact obtained makes the units more qualified and more professional so that the goal of national education to educate the children of the nation is expected to be achieved.

Follow-up on the implementation of PAUD unit accreditation in Padangsidmpuan City, Padangsidmpuan district, one of which is to make periodic activities related to the accreditation budgeted in the APBD that are carried out continuously with the BAN PAUD and PNF programs, of course this is very helpful to all units that have not and have been accredited. The accredited unit also follows up by increasing the qualifications and competence of its educators in addition to meeting other standards such as facilities and infrastructure.

Government efforts to develop human resources through the PAUD and PAUD education units have pushed the education unit to meet eight National Education Standards. In the framework of meeting these standards, the central government and regional governments prepare education units to be ready to be accredited on an ongoing and ongoing basis in the hope that the accreditation process can improve the quality of education units, especially in the City of Padangsidimpuan, District of South Padangsidimpuan. Based on the interview results, data from the Padangsdimpuan City Education Office for South Padangsidmpuan District with a total of 17 units including 50\% have been accredited, 9 are accredited institutions and 8 institutions have $\mathrm{B}$ grades and 1 institution with $\mathrm{C}$.

Based on the data above and the results of interviews from several institutions, elements of the education office and assessors can be concluded that Accreditation is an activity of recognition and evaluation of an educational institution regarding the feasibility and performance of an educational institution conducted by the National School Accreditation Board/Accreditation Agency National PAUD and PNF which then results in the form of recognition of eligibility ranking. Accreditation is carried out because there are several objectives and benefits described above. It also has results in the form of accredited ranking certificates that can be classified into three, namely: $\mathrm{A}, \mathrm{B}$, and $\mathrm{C}$, each of which has a Very Good, Good and Enough value.

Provide an overview of the level of school performance that is used as a tool for coaching, developing and improving schools both in terms of quality, effectiveness, efficiency, productivity and innovation. Providing guarantees to the public that the school has been accredited and provides educational services that meet national accreditation standards. Providing services to the public that students get good service and in accordance with the requirements of national standards.

\section{Conclusion}

Conclusions from the results of the study: (1) Preparation of PAUD unit accreditation in Padangsidimpuan City Kec. South Padangsidimpuan carried out by all elements involved in the unit namely educators and educational staff. Preparation is carried out by fulfilling 8 National Education Standards (SNP), preparations made in the form of documents and implementing KBM in accordance with the curriculum, (2) Obstacles faced by PAUD units in submitting to the implementation of accreditation namely the limited knowledge of 
educators and education staff in knowing each item assessment instruments that must be met, teacher qualifications and competencies, as well as facilities and infrastructure that are less supportive, (3) Implementation of the accreditation unit of Padangsidimpuan City PAUD Unit. South Padangsidimpuan has reached $50 \%$ of the existing number of units with ratings B and $\mathrm{C}$. The implementation of accreditation is an activity that will continue to be carried out continuously and continuously, (4) The impact of accreditation on PAUD units in Padangsidimpuan City, Kec. South Padangsidimpuan provides knowledge to educators and education personnel about 8 PAUD standards that must be provided in their respective units, motivates educators and education personnel to improve their qualifications and competencies, and (5) Follow-up of the implementation of the PAUD unit in Padangsidimpuan Kec. South Padangsidimpuan that is providing motivation to institutions that have and have not been accredited to further improve the quality of services in PAUD units. Making PAUD quality and competitive. PAUD unit accreditation becomes a routine program that continues to be carried out in collaboration with education units and departments.

Suggestions delivered as follows: (1) For PAUD units should be able to further improve the quality and service in their respective units especially to be able to meet the 8 National Education Standards (SNP) and be able to carry out meaningful teaching and learning activities to maximize student achievement, (2) The Department of Education must continue to support and facilitate PAUD units in Padangsidimpuan City, South Padangsidimpuan Subdistrict to apply for accreditation by becoming good partners and continue to make programs related to unit quality recall, and (3) For BAN PAUD AND PNF should be a reliable quality assurance institution that can maintain the quality of education in order to achieve national education goals to be able to educate the nation's children.

\section{References}

Ananda, Rusydi. Profesi Pendidik Dan Tenaga Kependidikan. Medan: LPPPI, 2018. Arikunto, Suharsimi. Penilaian Program Pendidikan, Jakarta: Bumi Aksara, 2011.

Arifin, Anwar. Memahami Paradigma Baru Pendidikan Nasional dalam Undang-undang SISDIKNAS, Jakarta: Rineka Cipta, 2005.

Suryosubroto, B. Manajemen Pendidikan di Sekolah, Jakarta: Rineka Cipta, 2004.

Bastian, Indra, Akuntansi Pendidikan, Jakarta: Erlangga, 2006.

Danim, Sudarwan, Agenda Pembaruan Sistem Pendidikan, Yogyakarta: Pustaka Pelajar, 2003.

Departemen Pendidikan Nasional, Standar Nasional Pendidikan Peraturan Pemerintah No. 19. Tahun 2005, Jakarta, Sinar Grafika, 2005.

Fattah, Nanang, Manajemen Berbasis Sekolah, Bandung: Andira, 2002.

Ma'mur, Jamal Asmani, Tips Praktis Membangun Dan Mengolah Administrasi Sekolah, Jogjakarta: Diva Press,2011.

Juran, J.M. Kepemimpinan Mutu, Pedoman Peningkatan Mutu Untuk Meraih Keunggulan Kompetitif, Jakarta: Pustaka Binawan Presindo, 1995.

Undang-Undang Republik Indonesia No 20 Tahun 2003 tentang Sistem Pendidikan Nasional. Jakarta: Sinar Grafika.2003.

Undang-Undang Guru dan Dosen No 14 Tahun 2005. Jakarta: Sinar Grafika, 2006. 